\title{
A natural bacterial strain Bacillus pumilus 16: Identification and antibiotic resistance evaluation
}

\author{
Alena N. Irkitova', Angelina V. Malkova', Dina E. Dudnik ${ }^{1}$ \\ 1 Altai State University, 61 Lenina Pr., Barnaul, 656049, Russia \\ Corresponding author: Angelina V. Malkova (elen171987@gmail.com)
}

Academiceditor:A.Matsyura| Received24 November 2021 | Accepted28 November2021 | Published6December 2021

http://zoobank.org/0E47BC48-3D7C-499F-AC84-A60BED7ADDA7

Citation: Irkitova AN, Malkova AV, Dudnik DE (2021) A natural bacterial strain Bacillus pumilus 16: Identification and antibiotic resistance evaluation. Acta Biologica Sibirica 7: 391-406. https://doi.org/10.3897/abs.7.e78412

\begin{abstract}
Microbial biopreparations are actively used to prevent, diagnose, and treat infectious, allergic, tumor, and autoimmune diseases in humans and animals; to stimulate the growth and development of plant crops. Natural bacterial strains with valuable technical properties are a vital biological resource for developing new biopreparations and rotating already known microbial preparations in the world market. This study describes a new natural strain $B$. pumilus 16 , which was isolated from the rhizosphere of Cichorium. The strain was identified using morphological and physiological parameters, biochemical tests, and primers Pum-f. and Pum-r. Antibiotic sensitivity and antagonistic activity against Escherichia coli were determined by diffusion of discs and delayed antagonism methods, respectively. The new natural strain (like type strains) fermented arabinose, cellobiose, mannitol, mannose, salicin, sucrose, and trehalose, and gave a positive reaction to arginine dihydrolase, ONPG, Voges-Proskauer test. It also gave a negative reaction to inositol, raffinose, sorbitol, methyl-D-glucoside, inulin, and lecithinase. B. pumilus 16, unlike the test strains, was capable of fermenting citrate. Strain B. pumilus 16 was highly sensitive to cephalexin $(37.9 \pm 0.7 \mathrm{~mm})$ and enrofloxacin $(25.7 \pm 8.9 \mathrm{~mm})$; sensitive to oleandomycin $(17.1 \pm 1.9 \mathrm{~mm})$, benzylpenicillin $(18.5 \pm 1.2 \mathrm{~mm})$, and monomycin $(16.0 \pm 0.6 \mathrm{~mm})$; resistant to oxacillin. By the agar blocks method $(7.3 \pm 1.5 \mathrm{~mm})$, a more pronounced antagonism of the new strain against $E$. coli was recorded than by the method of agar wells $(5.3 \pm 0.6 \mathrm{~mm})$. Due to the level of antagonistic activity, B. pumilus 16 was more effective than the type strains (two of which did not show an antagonistic effect). On the basis of this, the new strain can be recommended for inclusion in the bacterial preparation composition for the national economy.
\end{abstract}

Copyright Alena N. Irkitova et al. This is an open access article distributed under the terms of the Creative Commons Attribution License (CC BY 4.0), which permits unrestricted use, distribution, and reproduction in any medium, provided the original author and source are credited. 


\section{Keywords}

Bacillus pumilus, rhizosphere, antagonism, antibiotic resistance, Escherichia coli

\section{Introduction}

Biological preparations, including microbial bio preparations, are actively used to prevent, diagnose, and treat an infectious, allergic, tumor, and autoimmune diseases in humans and animals. Biological preparations stimulate the growth and development of plant crops (Kyrychenko 2015; Johnston et al. 2018). Natural bacterial strains with valuable technical properties are a vital biological resource for developing new biopreparations and rotation of already known microbial preparations in the world market. Currently, bacteria of the genus Bacillus are one of the most studied groups of microorganisms. They are widely used in various sectors of the economy (Ruiz-Garcia et al. 2005; Baruzzi et al. 2011; Cihan et al. 2012). The genus Bacillus belongs to the Firmicutes phylum and includes more than 200 species. Representatives of this taxon are Gram-positive rods, capable of forming endospores (Ten et al. 2006; Zeigler and Perkins 2008). In relation to oxygen bacilli, they can be obligate aerobes and facultative anaerobes. Therefore, they are widespread (Earl et al. 2008; Connor et al. 2010; Mathew and Krishnamurthy 2018).

B. subtilis is a type of the genus Bacillus. It is actively used in medicine, veterinary medicine, crop production, etc. (Shahcheraghi et al. 2015; Vogt et al. 2018; Wang et al. 2018). Taxonomists even distinguish the Bacillus subtilis group, which, in addition to B. subtilis, includes the following species: B. amyloliquefaciens, B. atrophaeus, B. axarquiensis, B. licheniformis, B. malacitensis, B. mojavensis, B. pumilus, B. sonorensis, B. tequilensis, B. vallismortis and B. velezensis (Jeyaram et al. 2011; Alina et al. 2015). Such species as B. licheniformis established themselves as an effective producer of enzymes and an active antagonist against pathogenic microorganisms (Schallmey et al. 2004; Alvarez-Ordóñez et al. 2014). However, the biological activity of $B$. pumilus has not yet been adequately studied.

It is known that $B$. pumilus is highly resistant to extreme environmental conditions such as low or no nutrient availability, desiccation, irradiation, and $\mathrm{H} 2 \mathrm{O} 2$ and chemical disinfectants. Many strains of B. pumilus are sensitive to tetracycline, kanamycin, erythromycin, vancomycin, and resistant to penicillin. Recently, it was also established that B. pumilus is marked with antifungal and antibacterial activity (Parvathi et al. 2009; Gao et al. 2017; Chu et al. 2019; Morita et al. 2019) against plant and animal pathogens. The constant search and study of active natural strains of microorganisms that are antagonists of pathogenic microbes are relevant because collections of bacterial cultures play a crucial role in mobilizing biological resources and make it possible to form a solid base for genetic, molecular, biological, and biotechnological studies.

This research aimed to identify and study the characteristics of a new natural strain isolated as an antagonist against Escherichia coli. 


\section{Material and methods}

The bacterial type strains, namely, B. pumilus B-7886, B. pumilus B-7917, B. pumilus B-7919, and B. subtilis B-1323 were procured from the Russian National Collection of Industrial Microorganisms (VKPM). The L-broth was used for the accumulation of biomass of bacteria of the genus Bacillus and E. coli and to conduct experiments on the study of direct antagonism. L-broth is made up of yeast extract $(5 \mathrm{~g} / \mathrm{L})$, peptone (15 g/L), and $\mathrm{NaCl}$ (5 g/L) (FBIS SRCAMB, Russia, 2018). Solid L-medium obtained by adding agar $(15 \mathrm{~g} / \mathrm{L})$ to the L-broth was used to assess the purity of bacterial cultures and to study delayed antagonism and antibiotic resistance. The $\mathrm{pH}$ index was adjusted at $7.0 \pm 0.2$.

Cultures of Bacillus spp. in L-broth were grown at $37^{\circ} \mathrm{C}$ in shaker-incubator "Innova 44" (New Brunswik, USA, 2015) at $250 \mathrm{rpm}$ for 18-24 hours. E. coli cultures in liquid and agarized medium and plates to study delayed antagonism and antibiotic resistance were grown on a thermostat 'Binder BD 115' (Binder, German, 2014) at $37^{\circ} \mathrm{C}$ for $18-24$ hours. As research materials, more than 100 samples of the rhizosphere of plants were selected from six administrative-territorial divisions of the Altai Krai (Russia). Bacillus sp. strains were isolated from the rhizosphere using standard sampling methods, ten-fold serial dilutions, and the spread plate method (Eremina and Krieger 2005; Shirokikh and Merzaev 2007). The general experimental scheme is shown below (Fig. 1).

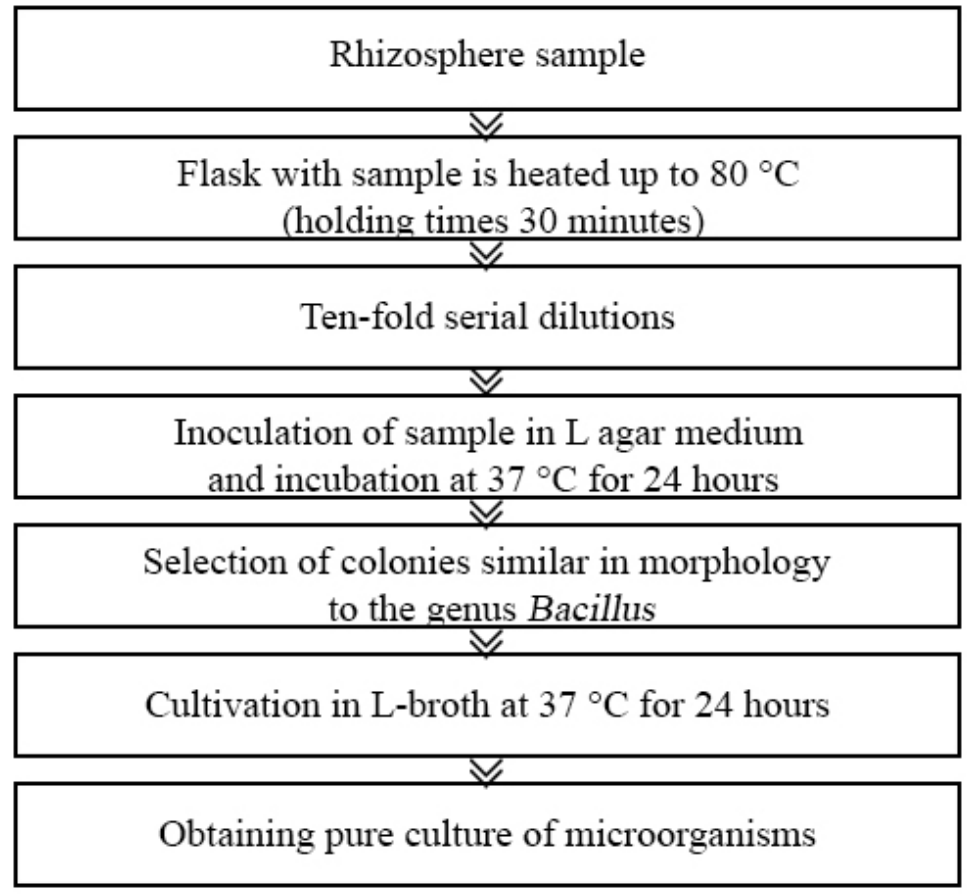

Figure 1. The isolation and identification scheme of rhizosphere microorganisms. 
The identification of rhizobacterial strains up to the genus Bacillus was carried out following the Bergey's Manual. The reaction to lecithinase established the safety of the isolated strains. It is negative for nonpathogenic representatives of the genus Bacillus.

Analysis of the nucleotide sequence of the 16S rRNA gene was used to confirm the belonging of the strain to the genus Bacillus. Subsequent screening using the GenBank and RDP-II databases was used for further identification of the species. Primers Pum-f, Pum-r, Saf-f, and Saf-r were used in PCR.

The Microgen Bacillus ID system was used for the biochemical characterization and identification of a novel strain.

The following antibiotics were used to study antibiotic resistance: cephalexin, oleandomycin, enrofloxacin, benzylpenicillin, oxacillin, and monomycin. The disk diffusion test determined the antibiotic resistance of the Bacillus strains. The spread plate method was used for the inoculation of Bacillus spp. strains in L-medium. The antibiotics were then placed on agar plates. The plates were incubated in a thermostat at $37^{\circ} \mathrm{C}$ for 24 hours. Zones of inhibition were recorded after cultivation. If the zone inhibition diameter was $<10 \mathrm{~mm}$, the strain was considered resistant, 10-15 $\mathrm{mm}$ as insensitive, and 15-20 $\mathrm{mm}$ as sensitive. Zones greater than $25 \mathrm{~mm}$ indicate a high sensitivity of the microorganism to this antibiotic (Vos et al. 2009; Horváth et al. 2016).

The antagonistic activity was tested against the Escherichia coli strain from microorganism collection from the Engineering Center "Prombiotech" (Barnaul, Russia). This bacterium was isolated from the waste products of chickens from the poultry farm.

Agar wells method. The pour-plate method was used for the inoculation of $E$. coli culture in L-medium. The plates were allowed to solidify at room temperature. Then, 5-7 mm diameter wells were made in each plate with a drill, and 30-40 $\mu \mathrm{l}$ of bacilli strain suspension were charged into the wells. The plates were incubated in a thermostat at $37^{\circ} \mathrm{C}$ for 24 hours. The radius of the inhibition zone around the charged wells was recorded after incubation.

Agar blocks method. The spread plate method was used for the inoculation of Bacillus spp. strains in L-medium. After that, the plates were incubated in a thermostat at $37^{\circ} \mathrm{C}$ for 24 hours. Next, the agar blocks with the grown bacillus culture were cut with the help of a sterile drill and placed on the surface of the agar medium with E. coli culture inoculated by the pour plate method. After this, the plates were incubated in a thermostat at $37^{\circ} \mathrm{C}$ for 24 hours. The radius of the inhibition zone around the agar blocks was recorded after incubation (Irkitova and Kagan 2012; Wang et al. 2017).

The studies were carried out in triplicate. The arithmetic average $(\mathrm{x})$ and the standard deviation (SD) were determined for the methods of delayed antagonism and the disk diffusion test. 


\section{Results}

Based on the morphology and basic properties corresponding to the genus Bacillus, we obtained 33 bacterial strains from 107 plant samples. Only eight isolates showed an adverse reaction to lecithinase. Strain No. 16, isolated from the rhizosphere of Cichorium, showed the highest antagonistic activity against $E$. coli. This isolate was selected for further analysis.

The colonies of B. pumilus 16 are of whitish to cream color (edge more transparent), matt, circular, raised, undulate, and approximately 0.5 to $0.8 \mathrm{~cm}$ in diameter after incubation for one day on L-agar at $37^{\circ} \mathrm{C}$ (Fig. 2).

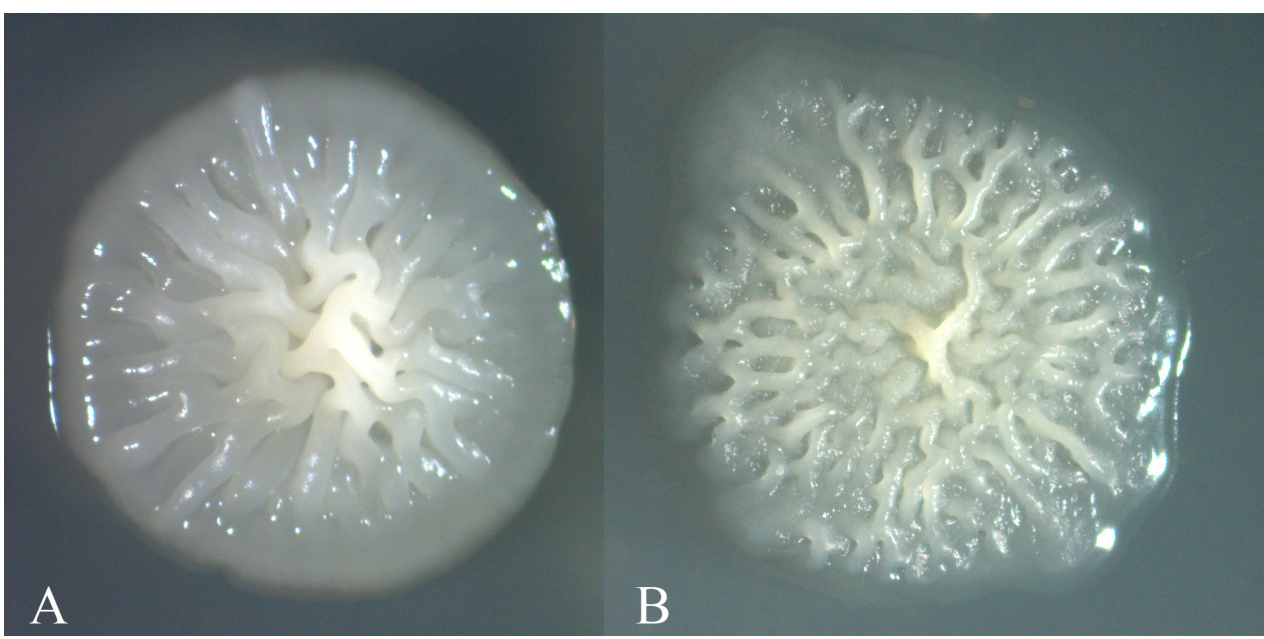

Figure 2. Morphology of the Bacillus genus colonies. A - the novel strain of B. pumilus (16). B - the B. subtilis B-1323 strain.

Like typical cultures, the novel strain, after cultivation in a shaking incubator for 18-24 hours, causes a clouding of the L-broth. A precipitate is formed in the flask after hours of rest. When B. pumilus 16 is cultivated in a thermostat. A folded film is formed on the surface of the broth, which is easily destroyed by shaking (Fig. 3). The optimal cultivation temperature of the new strain is $37^{\circ} \mathrm{C}$; $\mathrm{pH}$ is $6.8-7.0$.

The microscopic study of new strains showed that these bacteria are rods with a length of about 5-7 $\mu \mathrm{m}$ and $1 \mu \mathrm{m}$ in diameter. Cells occur singly, in pairs, and occasionally in short chains (Fig. 4, A). B. pumilus 16 produces oval-shaped central endospores (Fig. 4, B).

The initial selection of the nucleotide sequence (obtained by sequencing the variable regions of genes encoding $16 \mathrm{~S}$ rRNA) using the GenBank database and the Ribosomal Database Project II (RDP-II) showed that the studied strain belongs to the following systematic groups: Bacteria, Firmicutes, Bacilli, Bacillales, Bacillaceae, Bacillus. 
The results of the processing of sequences using a computer program, located on the RDB II website (Ribosomal Database Project II), designed to determine the affinity of microorganisms and build phylogenetic trees, are presented in graphical form (Fig. 5).

During the PCR reaction, the following primers were used: specific for Bacillus pumilus (gyrA) - Pum-f and Pum-r (Fig. 6), specific for Bacillus safeness (gyrA) Saf-f and Saf-r.

A fragment of $774 \mathrm{bp}$ was obtained using species-specific primers Pum-f and Pum-r. When we used primers Saf-f and Saf-r, fragments were not obtained. This made it possible to attribute the new strain to the Bacillus pumilus.

To study the biological activity of the new strain, we performed 29 tests (Table 1). The first five tests were taken from Bergey's Manual and allowed us to establish the belonging of the strain to the genus Bacillus and the level of its pathogenicity.

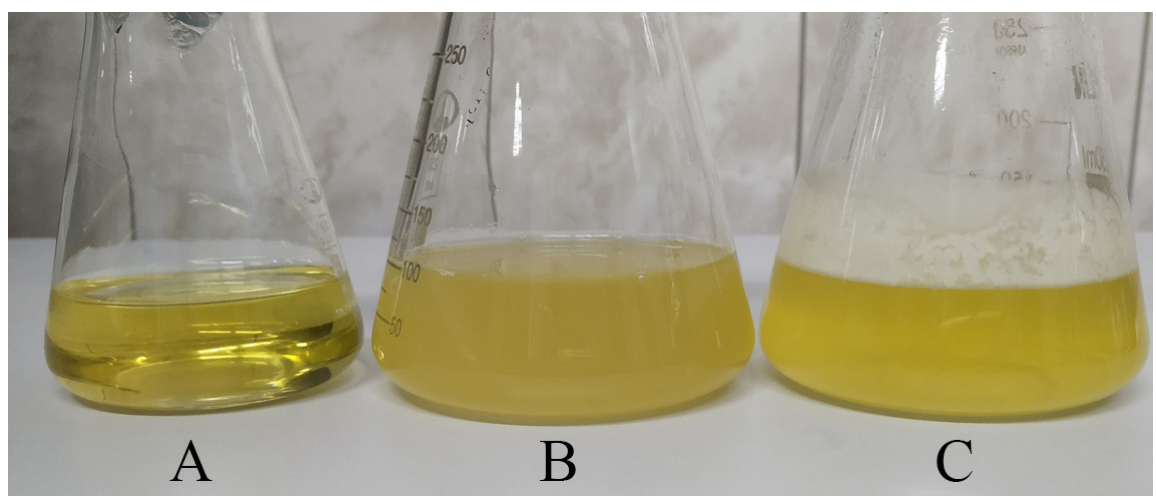

Figure 3. Growth of B. pumilus 16 in the L-broth. A - the sterile medium. B - 24-hour bacterial culture, which was incubated in a shaker. $\mathbf{C}$ - 24-hour bacterial culture, which was incubated in a thermostat.

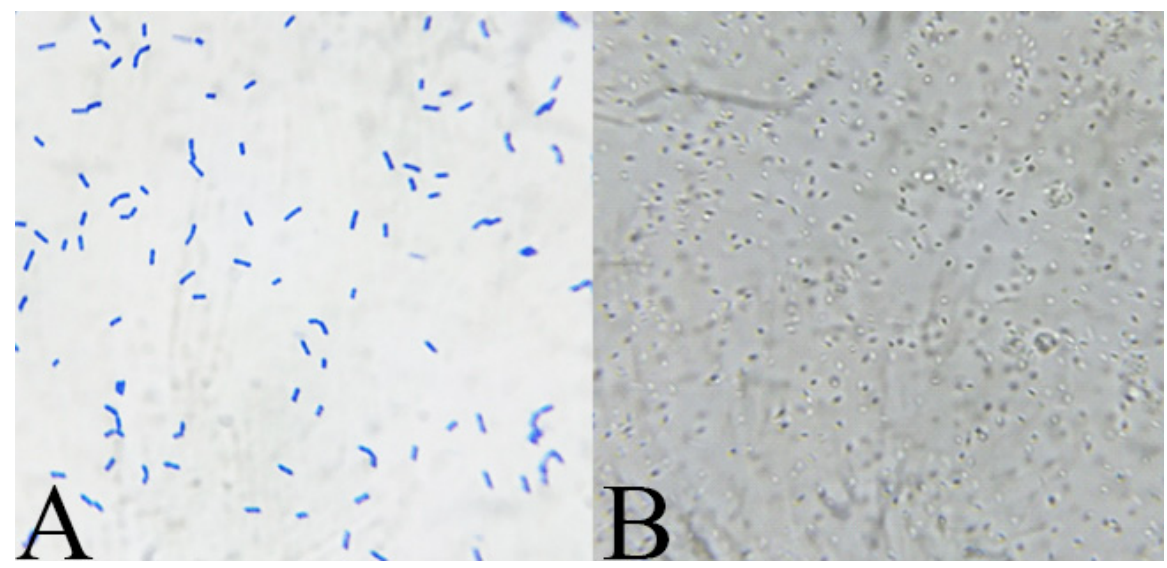

Figure 4. A novel strain under a microscope (x1000). A - Methylene blue-stained cells. B - The spores. 


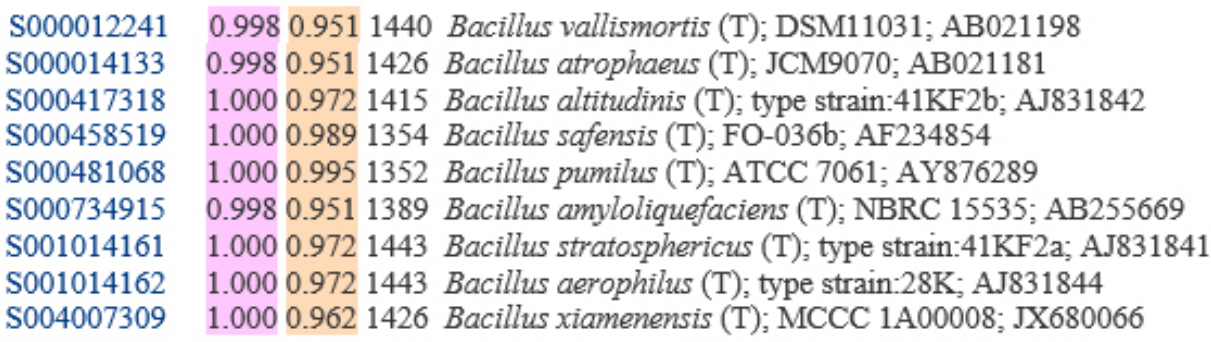

Figure 5. Sequence processing results.

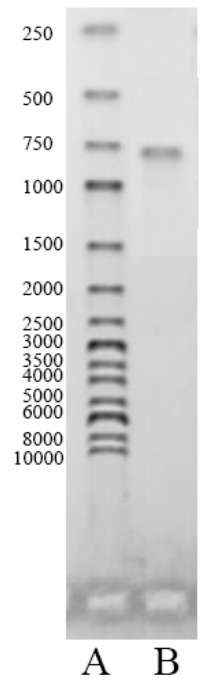

Figure 6. Results of the PCR analysis. A - Thermo Scientific O'GeneRuler $1 \mathrm{~kb}$ DNA Ladder. B - PCR analysis of the B. pumilus 16 strain using Pum-f and Pum-r primers.

Table 1. Comparison of the biochemical and physiological characteristics of B. pumilus 16 and type strains

\begin{tabular}{|c|c|c|c|c|c|}
\hline \multirow[t]{2}{*}{ Features } & \multicolumn{5}{|c|}{ Strains } \\
\hline & $\begin{array}{l}\text { B. pumilus } \\
16\end{array}$ & $\begin{array}{l}\text { B. pumilus } \\
\text { B-7886 }\end{array}$ & $\begin{array}{l}\text { B. pumilus } \\
\text { B-7917 }\end{array}$ & $\begin{array}{l}\text { B. pumilus } \\
\text { B-7919 }\end{array}$ & $\begin{array}{l}\text { B. subtilis } \\
\text { B-1323 }\end{array}$ \\
\hline Gram staining & + & + & + & + & + \\
\hline Spore formation & + & + & + & + & + \\
\hline Anaerobic growth & - & - & - & - & - \\
\hline Catalase & + & + & + & + & + \\
\hline \multirow[t]{2}{*}{ Lecithinase } & - & - & - & - & - \\
\hline & \multicolumn{5}{|c|}{ Substrates } \\
\hline Arabinose & + & + & + & + & + \\
\hline Cellobiose & + & + & + & + & + \\
\hline
\end{tabular}




\begin{tabular}{|c|c|c|c|c|c|}
\hline \multirow[t]{2}{*}{ Features } & \multicolumn{5}{|c|}{ Strains } \\
\hline & $\begin{array}{l}\text { B. pumilus } \\
16\end{array}$ & $\begin{array}{l}\text { B. pumilus } \\
\text { B-7886 }\end{array}$ & $\begin{array}{l}\text { B. pumilus } \\
\text { B-7917 }\end{array}$ & $\begin{array}{l}\text { B. pumilus } \\
\text { B-7919 }\end{array}$ & $\begin{array}{l}\text { B. subtilis } \\
\text { B-1323 }\end{array}$ \\
\hline Inositol & - & - & - & - & + \\
\hline Mannitol & + & + & + & + & + \\
\hline Mannose & + & + & + & + & + \\
\hline Raffinose & - & - & - & - & + \\
\hline Rhamnose & - & - & - & - & - \\
\hline Salicin & + & + & + & + & + \\
\hline Sorbitol & - & - & - & - & + \\
\hline Sucrose & + & + & + & + & + \\
\hline Trehalose & + & + & + & + & + \\
\hline Xylose & - & + & + & + & - \\
\hline Adonitol & - & - & - & - & - \\
\hline Galactose & - & - & + & - & - \\
\hline Methyl-D-Mannoside & - & - & - & - & - \\
\hline Methyl-D-Glucoside & - & - & - & - & + \\
\hline Inulin & - & - & - & - & + \\
\hline Melezitose & - & - & - & - & - \\
\hline Indole & - & - & - & - & - \\
\hline ONPG & + & + & + & + & + \\
\hline Nitrate & - & - & - & - & + \\
\hline $\begin{array}{l}\text { Arginine } \\
\text { Dihydrolase }\end{array}$ & + & + & + & + & + \\
\hline $\begin{array}{l}\text { Citrate } \\
\text { Utilization }\end{array}$ & + & - & - & - & - \\
\hline $\begin{array}{l}\text { Voges } \\
\text { Proskauer }\end{array}$ & + & + & + & + & - \\
\hline
\end{tabular}

Notes: “+” - positive reaction, “-” - negative reaction, ONPG - O-nitrophenyl-beta-D-galactopyranoside.

Strain B. pumilus 16, like reference strains, is Gram positive, spore-forming, catalase positive, lecithinase negative, and not capable of growth under anaerobic conditions.

Like other B. pumilus strains (B-7886, B-7917, B-7919), the new rhizosphere strain can ferment such carbohydrates as arabinose, cellobiose, mannitol, mannose, salicin, sucrose, and trehalose. It also hydrolyzes ONPG and gives a positive reaction to arginine dihydrolase and the Voges-Proskauer test. However, the specificity of the new strain of B. pumilus 16 is the inability to ferment xylose. 
Differences in biochemical characteristics between B. pumilus 16 and B. subtilis B-1323 are more significant. The studied strain does not ferment inositol, raffinose, sorbitol, methyl-D-glucoside, and inulin. It does not reduce nitrate and forms acetoin, unlike $B$. subtilis B-1323. A significant difference between new and type strains is the ability of $B$. pumilus 16 to use citrate as the sole carbon source. The novel strain was close to the type strains in terms of antibiotic resistance (Table 2).

Table 2. Antibiotic resistance $(\mathrm{mm}(\mathrm{x} \pm \mathrm{SD})$ of a novel and type strains

\begin{tabular}{llllll}
\hline Antibiotics & Strains \\
& $\begin{array}{lll}\text { B. pumilus } \\
\text { 16 }\end{array}$ & $\begin{array}{l}\text { B. pumilus } \\
\text { B-7886 }\end{array}$ & $\begin{array}{l}\text { B. pumilus } \\
\text { B-7917 }\end{array}$ & $\begin{array}{l}\text { B. pumilus } \\
\text { B-7919 }\end{array}$ & $\begin{array}{l}\text { B. subtilis } \\
\text { B-1323 }\end{array}$ \\
\hline Cephalexin & $37.9 \pm 0.7$ & $32.7 \pm 2.5$ & $36.7 \pm 3.8$ & $35.0 \pm 1.7$ & $32.7 \pm 2.8$ \\
& $(+++)$ & $(+++)$ & $(+++)$ & $(+++)$ & $(+++)$ \\
Oleandomycin & $17.1 \pm 1.9$ & $16.7 \pm 0.6$ & $14.7 \pm 0.6$ & $16.3 \pm 1.2$ & $15.7 \pm 0.6$ \\
& $(++)$ & $(++)$ & $(+)$ & $(++)$ & $(++)$ \\
Enrofloxacin & $25.7 \pm 8.9$ & $27.3 \pm 0.6$ & $28.0 \pm 1.0$ & $27.0 \pm 1.0$ & $27.0 \pm 1.0$ \\
& $(+++)$ & $(+++)$ & $(+++)$ & $(+++)$ & $(+++)$ \\
Benzylpenicillin & $18.5 \pm 1.2$ & $13.3 \pm 0.6$ & $16.3 \pm 2.1$ & $13.7 \pm 1.2$ & 0 \\
& $(++)$ & $(+)$ & $(++)$ & $(+)$ & $(-)$ \\
Oxacillin & 0 & 0 & 0 & 0 & 0 \\
& $(-)$ & $(-)$ & $(-)$ & $(-)$ & $(-)$ \\
Monomycin & $16.0 \pm 0.6$ & $14.3 \pm 0.6$ & $13.3 \pm 0.6$ & $13.7 \pm 0.6$ & $15.3 \pm 1.2$ \\
& $(++)$ & $(+)$ & $(+)$ & $(+)$ & $(++)$ \\
\hline
\end{tabular}

Note: “-" - resistance, “+” - insensitive, “++" - sensitive, “+++" - highly sensitive.

Strain B. pumilus 16 , like all types of strains, was resistant to oxacillin. The strain B. subtilis B-1323 also showed resistance to benzylpenicillin. Sensitivity for other antibiotics was recorded, including high sensitivity. The least resistance to cephalexin and enrofloxacin was observed.

Table 3 shows the results of the antagonistic activity of the new strain against $E$. coli. Antagonism was fixed in both techniques for researching delayed antagonism.

Table 3. Radii of growth inhibition zones ( $\mathrm{mm}(\mathrm{x} \pm \mathrm{SD})$ of E. coli by B. pumilus 16 and type strains

\begin{tabular}{llllll}
\hline Methods & \multicolumn{5}{c}{ Strains } \\
& $\begin{array}{lll}\text { B. pumilus } \\
\text { 16 }\end{array}$ & $\begin{array}{l}\text { B. pumilus } \\
\text { B-7886 }\end{array}$ & $\begin{array}{l}\text { B. pumilus } \\
\text { B-7917 }\end{array}$ & $\begin{array}{l}\text { B. pumilus } \\
\text { B-7919 }\end{array}$ & $\begin{array}{l}\text { B. subtilis } \\
\text { B-1323 }\end{array}$ \\
\hline Agar blocks & $7.3 \pm 1.5$ & 0 & 0 & $1.1 \pm 0.1$ & $1.5 \pm 0.5$ \\
Agar wells & $5.3 \pm 0.6$ & 0 & 0 & $2.7 \pm 0.6$ & 0 \\
\hline
\end{tabular}


Reference strains of B. pumilus B-7886 and B-7917 did not exert an inhibitory effect on E. coli. The antimicrobial effect of B. subtilis B-1323 was only recorded by the agar block method.

The strain B. pumilus B-7919 also showed an antagonistic effect in both methods to determine delayed antagonism, as well as B. pumilus 16 . However, the growth blocking zones of E. coli by the novel strain was maximal (Fig. 7).

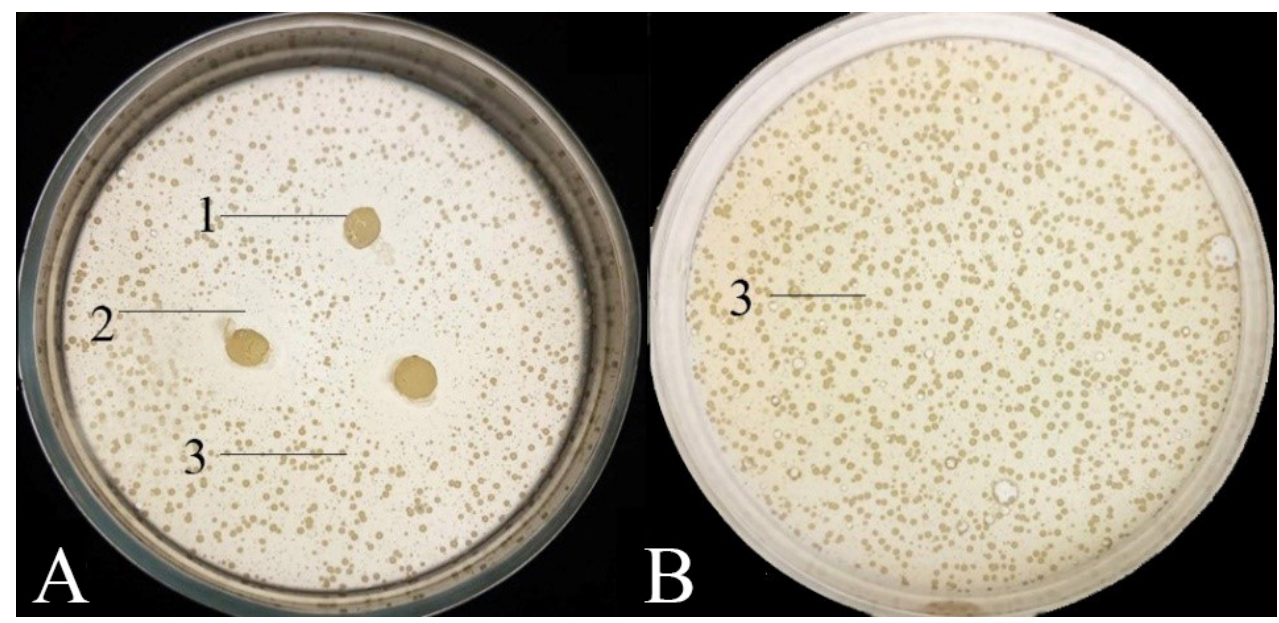

Figure 7. Antagonistic activity of B. pumilus 16 against E. coli. A - Plate with agar blocks. B - Control plate. 1. Block with antagonist strain. 2. The zone of growth inhibition. 3. Test culture.

\section{Discussion}

The new strain isolated from the rhizosphere of Cichorium is marked with R-colonies typical for representatives of the B. subtilis, culture conditions, rod-shaped cells, and spore-forming ability. According to Bergey's Manual, the combination of physiological and biochemical features of the new strain indicates that it belongs to non-pathogenic bacilli. As a result of the sequencing of variable regions of genes encoding $16 \mathrm{~S}$ rRNA and PCR analysis using species-specific primers (Venkataramana 2015; Mukhtar et al. 2018), the studied strain can be assigned to the Bacillus pumilus. Based on these results, strain B. pumilus 16 was deposited in VKPM under No. B-13250. We obtained the patent under No. 2, 694, 522 (RU).

The biochemical characteristics of B. pumilus 16 and the reference strains have significant similarities due to their belonging to the same phylogenetic group, the Bacillus subtilis group (BacDive, n.d.). Latorre et al. (2016) also demonstrated: "Not all Bacillus spp. synthesize the same enzyme types". Differences in biochemical activity are determined by the variety of ferment produced, which is associated with the variability of the bacterial genome. Furthermore, differences in the use of cer- 
tain substrates as a source of carbon and energy are associated with the influence of environmental conditions to which these strains are adapted.

We have previously found (Orlova et al. 2020) that the new strain of B. pumilus 16 in terms of antibiotic sensitivity was close to the reference strains. According to published data, bacilli are often resistant to antibiotics of the penicillin group, including oxacillin (Andrews and Wise 2002; Owusu-Kwarteng et al. 2017), which was confirmed in our study. At the same time, new strains and reference strains of the same species were sensitive to benzylpenicillin because they did not have a penicillinase enzyme, which destroys this antibiotic. The high sensitivity of B. pumilus 16 and all type cultures to cephalexin can be explained by the fact that this antibiotic is resistant to $\beta$-lactamases, bacterial enzymes aimed at combating $\beta$-lactam antibiotics from the penicillin group. Enrofloxacin, related to fluoroquinolones, is effective against aerobic gram-positive bacteria, to which a new strain belongs (Ismail and Adeloju 2010; Bush and Bradford 2016; Trouchon and Lefebvre 2016).

B. pumilus 16 is sensitive to 5 of the 6 antibiotics used. Therefore, if this microorganism is used in various sectors of the national economy, it will not transfer antibiotic resistance genes to pathogenic bacteria. On the other hand, this fact makes it impossible to use a probiotic containing the B. pumilus 16 strain during antibiotic therapy of the antibiotic compounds studied (Wintersdorff et al. 2016; Kerna and Brown 2018; Sun et al. 2019).

The new strain is marked with higher antagonistic activity compared to the reference strains. This may be because the strain studied is natural and, therefore, more stable, since the struggle for existence is constant under conditions of high density of microorganisms on the root surface. This leads to the development of various mechanisms of suppression of competitors (Krober et al. 2014; Andrić et al. 2020). Furthermore, the $B$. pumilus 16 strain, unlike type strains, was recently isolated. Thus, it has not yet lost its effectiveness under laboratory conditions.

Liu et al. (2019) confirmed that surfactin synthesized by B. subtilis is effective against E. coli. Xiu et al. (2017) isolated from B. pumilus a surfactin-like antibiotic, pumilacidin, which was effective against Vibrio alginolyticus. Saggese et al. (2018) proved that pumylacidin is active against Staphylococcus aureus. This indicates that bacilli synthesize various substances with antimicrobial activity with a wide spectrum of antimicrobial activity. According to our previous results (Funk et al. 2019), $B$. pumilus 16 inhibited the growth of $E$. coli in both techniques to investigate delayed antagonism. Successful inhibition of E. coli growth by B. pumilus 16 using various methods to determine antagonistic activity may indicate the strain's ability to synthesize different antimicrobial compounds. Because various mechanisms of antagonism are triggered. But more research is needed to confirm this assumption. 


\section{Conclusion}

Thus, a new strain 16, which was isolated from the rhizosphere of Cichorium, was identified as B. pumilus. The strain was deposited in VKPM (Russian National Collection of Industrial Microorganisms) under No. B-13250 and patented under No. 2, 694, 522 (RU). B. pumilus 16 did not show resistance to antibiotics of the aminoglycoside group, cephalosporins, and benzylpenicillin (the zone of growth inhibition ranged from 16.0 to $37.9 \mathrm{~mm}$ ). The strain studied in terms of antagonistic activity against $E$. coli is superior to the reference strains $B$. pumilus B-7886, $B$. pumilus B-7917, B. pumilus B-7919, and B. subtilis B-1323. In connection with the above facts, the novel strain of $B$. pumilus 16 is a valuable biological resource. It is promising for use as an active component in biological preparations.

\section{References}

Alina SO, Constantinescu F, Cornea CP (2015) Biodiversity of Bacillus subtilis group and beneficial traits of Bacillus species useful in plant protection. Romanian Biotechnological Letters 20: 10737-10750.

Alvarez-Ordóñez A, Begley M, Clifford T, Deasy T, Considine K, O’Connor P, Ross RP, Hill C (2014) Investigation of the antimicrobial activity of Bacillus licheniformis strains isolated from retail powdered infant milk formulae. Probiotics and Antimicrobial Proteins 6: 32-40. http://doi.org/10.1007/s12602-013-9151-1

Andrews JM, Wise R (2002) Susceptibility testing of Bacillus species. Journal of Antimicrobial Chemotherapy 49: 1040-1042. http://doi.org/10.1093/jac/dkf063

Andrić S, Meyer T, Ongena M (2020) Bacillus Responses to plant-associated fungal and bacterial communities. Frontiers in Microbiology 11: 1350. http://doi. org/10.3389/fmicb.2020.01350

BacDive - The Bacterial Diversity Metadatabase: Bacillus pumilus 272 is a mesophilic human pathogen of the family Bacillaceae. https://bacdive.dsmz.de/ strain/756

Baruzzi F, Quintieri L, Morea M, Caputo L (2011) Antimicrobial compounds produced by Bacillus spp. and applications in food. In: Vila AM (Ed.) Science against microbial pathogens: Communicating current Research and Technological Advances 2. Formatex Research Center, Badajoz, Spain, 1102-1111.

Bush K, Bradford PA (2016) $\beta$-Lactams and $\beta$-Lactamase inhibitors: An overview. Cold Spring Harbor Perspectives in Medicine 6: a025247. http://doi. org/10.1101/cshperspect.a025247

Chu J, Wang Y, Zhao B, Zhang XM, Liu K, Mao L, Kalamiyets E (2019) Isolation and identification of new antibacterial compounds from Bacillus pumilus. Applied Microbiology and Biotechnology 103: 1-7. http://doi.org/10.1007/s00253-01910083-y 
Cihan AC, Tekin N, Ozcan B, Cokmus C (2012) The genetic diversity of genus Bacillus and the related genera revealed by 16s rRNA gene sequences and Ardra analyses isolated from geothermal regions of Turkey. Brazilian Journal of Microbiology 43: 309-324. https://doi.org/10.1590/S1517-83822012000100037

Connor N, Sikorski J, Rooney AP, Kopac S, Koeppel AF, Burger A, Cole SG, Perry EB, Krizanc B, Field NC, Slaton M, Field NC (2010) Ecology of speciation in the genus Bacillus. Applied and Environmental Microbiology 76: 1349-1358. http:// doi.org/10.1128/AEM.01988-09

Earl AM, Losick R, Kolter R (2008) Ecology and genomics of Bacillus subtilis. Trends in Microbiology 16(6): 269-275. http://doi.org/10.1016/j.tim.2008.03.004

Eremina IA, Krieger OV (2005) Microbiology laboratory workshop. Kemerovo Institute of Food Technology, Kemerovo, Russia, 112 pp. [In Russian]

Funk IA, Irkitova AN, Grebenshchikova AV, Dudnik DY (2019) Antagonistic activity of strains of Bacillus Pumilus being promising for inclusion in a probiotic product for animals. Bulletin of Altai State Agrarian University 12: 126-130. [In Russian]

Gao XY, Liu Y, Miao LL, Li EW, Hou TT, Liu ZP (2017) The mechanism of antiVibrio activity of marine probiotic strain Bacillus pumilus $\mathrm{H} 2$, and characterization of the active substance. AMB Express 7: 23. http://doi.org/10.1186/s13568017-0323-3

Horváth G, Bencsik T, Ács K, Kocsis B (2016) Sensitivity of ESBL-producing gramnegative bacteria to essential oils, plant extracts, and their isolated compounds. In: Kon K, Rai M (Eds) Antibiotic Resistance. Academic Press, London, 239269.

Irkitova AN, Kagan YR (2012) Comparative analysis of methods for determining the antagonistic activity of lactic acid bacteria. Izvestiya of the Altai State University 3: 41-44. [In Russian]

Ismail F, Adeloju SB (2010) Galvanostatic entrapment of penicillinase into polytyramine films and its utilization for the potentiometric determination of penicillin. Sensors 10: 2851-2868. http://doi.org/10.3390/s100402851

Jeyaram K, Romi W, Singh TA, Adewumi GA, Basanti K, Oguntoyinbo FA (2011) Distinct differentia-tion of closely related species of Bacillus subtilis group with industrial importance. Journal of Microbiological Methods 87: 161-164.

Johnston BC, Lytvyn L, Lo CKF, Allen SJ, Wang D, Szajewska H, Miller M, Ehrhardt S, Sampalis J, Duman DJ, Pozzoni P, Colli A, Lönnermark E, Selinger CP, Wong S, Plummer S, Hickson M, Pancheva R, Hirsch S, Klarin B, Goldenberg JZ. Wang L, Mbuagbaw L, Foster G, Maw A, Sadeghirad B, Thabane L, Mertz D (2018) Microbial preparations (probiotics) for the prevention of clostridium difficile infection in adults and children: An individual patient data meta-analysis of 6,851 participants. Infection Control \& Hospital Epidemiology 39: 771-781. http://doi.org/10.1017/ice.2018.84

Kerna NA, Brown TL (2018) A complementary medicine approach to augmenting antibiotic therapy current practices in the use of probiotics during antibiotic 
therapy. International Journal of Complementary \& Alternative Medicine 11(2): 62-66. http://doi.org/10.15406/ijcam.2018.11.00368

Krober M, Wibberg D, Grosch R, Eikmeyer F, Verwaaijen B, Chowdhury SP, Hartmann A, Pühler A, Schloter A (2014) Effect of the strain Bacillus amyloliquefaciens FZB42 on the microbial community in the rhizosphere of lettuce under field conditions analyzed by whole metagenome sequencing. Frontiers in Microbiology 5: 252. http://doi.org/10.3389/fmicb.2014.00252

Kyrychenko OV (2015) Market analysis and microbial bio preparations creation for crop growing in Ukraine. Biotechnologia Acta 8: 40-52. http://doi.org/10.15407/ biotech8.04.040

Latorre JD, Hernandez-Velasco X, Wolfenden RE, Vicente JL, Wolfenden AD, Menconi A, Bielke LR, Hargis BM, Tellez G (2016) Evaluation and selection of $B a-$ cillus species based on enzyme production, antimicrobial activity, and biofilm synthesis as direct-fed microbial candidates for poultry. Frontiers in Veterinary Science 3: 95. http://doi.org/10.1017/10.3389/fvets.2016.00095

Liu J, Wang X, Shi W, Qian Z, Wang Y (2019) Sensitization of avian pathogenic Escherichia coli to amoxicillin in vitro and in vivo in the presence of surfactin. PLOS ONE 14(9): e0222413. http://doi.org/10.1371/journal.pone.0222413

Mathew BB, Krishnamurthy NB (2018) Screening and identification of bacteria isolated from industrial area groundwater to study lead sorption: Kinetics and statistical optimization of biosorption parameters. Groundwater for Sustainable Development 7: 313-327.

Morita T, Tanaka I, Ryuda N, Ikari M, Ueno D, Someya T (2019) Antifungal spectrum characterization and identification of strong volatile organic compounds produced by Bacillus pumilus TM-R. Heliyon 5: e01817. http://doi.org/10.1016/j. heliyon.2019.e01817

Mukhtar T, Afridi MS, McArthur R, Van Hamme JD, Rineau F, Mahmood T, Amna, Sumaira, Zahid M, Salam A, Khan MN, Ali F, Mehmood S, Bangash N, Chaudhary HJ (2018) Draft genome sequence of Bacillus pumilus SCAL1, an endophytic heat-tolerant plant growth-promoting Bacterium. Genome Announcements 6: e00306-18. http://doi.org/10.1128/genomeA.00306-18

Orlova TN, Irkitova AN, Grebenshchikova AV, Dudnik DY (2020) The study of antibiotic susceptibility of a new rhizosphere strain Bacillus Pumilus B-13250 to use it in the composition of probiotic products for livestock. Bulletin of Altai State Agrarian University 1: 111-115. [In Russian]

Owusu-Kwarteng J, Wuni A, Akabanda F, Tano-Debrah K, Jespersen L (2017) Prevalence, virulence factor genes, and antibiotic resistance of Bacillus cereus sensu lato isolated from dairy farms and traditional dairy products. BMC Microbiology 17: 1-8. http://doi.org/10.1186/s12866-017-0975-9

Parvathi A, Krishna K, Jose J, Joseph N, Nair S (2009) Biochemical and molecular characterization of Bacillus pumilus isolated from coastal environment in Cochin, India. Brazilian Journal of Microbiology 40: 269-275. http://doi. org/10.1590/S1517-838220090002000012 
Ruiz-Garcıa C, Bejar V, Martınez-Checa F, Llamas I, Quesada E (2005) Bacillus velezensis sp. nov., a surfactant producing bacterium isolated from the river Ve' lez in Ma'laga, southern Spain. International Journal of Systematic and Evolutionary Microbiology 55: 191-195. http://doi.org/10.1099/ijs.0.63310-0

Saggese A, Culurciello R, Casillo A, Corsaro MM, Ricca E, Baccigalupi LA (2018) Marine isolate of Bacillus pumilus secretes a pumilacidin active against Staphylococcus aureus. Marine Drugs 16: E180. http://doi.org/10.3390/md16060180

Schallmey M, Singh A, Ward OP (2004) Developments in the use of Bacillus species for industrial production. Canadian Journal of Microbiology 50: 1-17. http:// doi.org/10.1139/W03-076

Shahcheraghi SH, Ayatollahi J, Lotfi M (2015) Applications of Bacillus subtilis as an important bacterium in medical sciences and human life. Tropical Journal of Medical Research 18: 1-4. http://doi.org/10.4103/1119-0388.152530

Shirokikh AA, Merzaev OV (2007) Methodological approaches to the study of microorganisms in the root zone of plants. Agricultural Biology 1: 43-55. [In Russian]

Sun D, Jeannot K, Xiao Y, Knapp CW (2019) Editorial: horizontal gene transfer mediated bacterial antibiotic resistance. Frontiers in Microbiology 10: 1093. http:// doi.org/10.3389/fmicb.2019.01933

Ten LN, Im WT, Baek SH, Lee JS (2006) Bacillus ginsengihumi sp. nov., a novel species isolated from soil of a ginseng field in Pocheon province. Korean Journal of Microbiology and Biotechnology 16: 1554-1560. http://doi.org/10.1007/ s10482-006-9102-x

Trouchon T, Lefebvre S (2016) A review of enrofloxacin for veterinary use. Open Journal of Veterinary Medicine 6: 40-58. http://doi.org/10.4236/ojvm.2016.62006

Vasiliev DA, Arkhipova GF, Nikolaychuk, LF (2013) Bacillus cereus bacteria and interspecific recombination with Bacillus anthracis as a threat to human health. Color-Print, Ulyanovsk, Russia, 90 pp. [In Russian]

Venkataramana K (2015) Bacterial capsule, colony morphology, functions, and its relation to virulence and diagnosis. Annals of Tropical Medicine and Public Health 8: 151-153. http://doi.org/10.4103/1755-6783.162409

Vogt CM, Armua-Fernandez MT, Tobler K, Hilbe M, Aguilar C, Ackermann M, Deplazes P, Eichwald C (2018) Oral application of recombinant bacillus subtilis spores to dogs results in a humoral response against specific echinococcus granulosus paramyosin and tropomyosin antigens. Infection and Immunity 86: e00495-17. http://doi.org/10.1128/IAI.00495-17

Vos P, Garrity G, Jones D, Krieg NR, Ludwig W, Rainey FA, Schleifer KH, Whitman WB (2009) Bergey's Manual of Systematic Bacteria (2nd ed.) (Vol. 3). SpringerVerlag, New York, 1317 pp.

Wang D, Ren H, Erihemu Zheng Z (2017) Isolation, identification and antagonistic activity evaluation of actinomycetes in barks of nine trees. Archives of Biological Sciences 69(2): 345-351. http://doi.org/10.2298/ABS160429109W 
Wang XQ, Zhao DL, Shen LL, Jing CL, Zhang CS (2018) Application and mechanisms of Bacillus subtilis in biological control of plant disease. In: Meena VS (Ed.) Role of rhizospheric microbes in soil (Vol. 1). Springer Nature, Singapore, 225-250

Wintersdorff CJH, Penders J, Niekerk JM, Mills ND, Majumder S, Alphen LB, Savelkoul PHM, Wolffs PFG (2016) Dissemination of Antimicrobial resistance in microbial ecosystems through horizontal gene transfer. Frontiers in Microbiology 7: 173. https://doi.org/10.3389/fmicb.2016.00173

Xiu P, Liu R, Zhang D, Sun C (2017) Pumilacidin-like lipopeptides derived from marine bacterium Bacillus sp. strain 176 suppress the motility of Vibrio alginolyticus. Applied and Environmental Microbiology 83(12): 1-36. https://doi. org/10.1128/AEM.00450-17

Zeigler DR, Perkins JB (2008) The Genus Bacillus. In: Goldman E, Green LH (Eds) Practical Handbook of Microbiology. CRC Press, Boca Raton, 309-333. 